\title{
Gene Expression From the Aneuploid Chromosome in a Trisomy Mouse Model of Down Syndrome
}

\author{
Robert Lyle, ${ }^{1}$ Corinne Gehrig, Charlotte Neergaard-Henrichsen, Samuel Deutsch, \\ and Stylianos E. Antonarakis
}

\author{
Department of Genetic Medicine and Development, University of Geneva Medical School and University Hospitals, \\ 1211 Geneva, Switzerland
}

\begin{abstract}
Trisomy 21 is the prototype of human aneuploidies. Since its discovery in 1959, the hypothesis has been that overexpression of the $\sim 230$ human chromosome 21 (Hsa21) genes result in the complex phenotype. However, the level of overexpression of Hsa2l genes in trisomic individuals is presently unknown. We have used Taqman real-time quantitative PCR to accurately measure expression of the mouse orthologs of Hsa21 in the partial trisomy mouse model Ts65Dn. The transcript levels of 78 protein-coding genes present in three copies in Ts65Dn and 21 control genes were compared between Ts65Dn and normal mouse littermates. The mean overexpression of the aneuploid genes is very close to the expected 1.5 -fold in all six tissues studied. However, only approximately a third of the genes (37\%) are expressed at the theoretical value of 1.5 -fold. On average, $45 \%$ of the genes are expressed at significantly lower than 1.5 -fold, and $9 \%$ are not significantly different from 1.0 . Interestingly, $18 \%$ of the aneuploid genes were expressed at levels significantly greater than 1.5 -fold. These data provide candidate genes that might be involved in the phenotypes of Down syndrome, and reveal a complex regulation of gene expression that is not only related to gene copy number.
\end{abstract}

[Supplemental material is available online at www.genome.org.]

The phenotype of trisomy 21 (Down Syndrome, DS) has two striking characteristics; the clinical features are highly variable, only mental retardation and muscle hypotonia are considered to be present in all individuals, and many features are present in the general population at a lower frequency (Epstein 2001). A major goal of understanding the molecular pathology of DS is the identification of genes that contribute to specific aspects of the phenotype. With the completion of the sequence of Hsa21 (Hattori et al. 2000), extensive gene annotation (Davisson et al. 2001; Pletcher et al. 2001; Reymond et al. 2001, 2002a), and the expression atlas (Reymond et al. 2002b) a wealth of data have accumulated on Hsa21 genes. However, the level of expression of these genes in aneuploidy has not been extensively studied. This information is important, as DS is caused by alterations in gene dosage, and candidate genes for DS phenotypes could be identified. Whereas it is often assumed that genes present in three copies in trisomic (Ts) individuals will be expressed 1.5-fold relative to euploid $(\mathrm{Eu})$, this has not been formally tested for individual genes.

The aim of this study was to accurately measure the expression of a large number of genes to determine the consequences of trisomy on the level of gene expression from the aneuploid chromosome. We used Taqman real-time quantitative PCR (qPCR) to study the expression of the genes triplicated in the Ts65Dn partial trisomy mouse model of DS (Davisson et al. 1990; Reeves et al. 1995). Ts65Dn mice have many aspects of the phenotype that characterize DS, for example, behavioral defects (Reeves et al. 1995) and cerebellar (Baxter et al. 2000) and craniofacial (Richtsmeier et al. 2000) abnormalities. We studied a total of 99 genes in two developmental stages (postnatal day 30 and $11 \mathrm{mo}$ ) and six different tissues (brain, heart, kidney, liver, lung, and muscle).

\footnotetext{
1Corresponding author.

E-MAIL Robert.Lyle@medicine.unige.ch; FAX 41-22-379-5706.

Article and publication are at http://www.genome.org/cgi/doi/10.1101/ gr.2090904.
}

\section{RESULTS}

Ts65Dn mice are trisomic for $\sim 16 \mathrm{Mb}$ of mouse Chromosome 16 , containing 105 Hsa21 orthologs, from Gabpa to Znf295 (Akeson et al. 2001; www.ensembl.org). We studied well-supported and annotated genes (known genes or transcripts with multiple ESTs) that could unambiguously be mapped to Hsa21. Mouse orthologs of Hsa21 genes were identified by reciprocal BLAST searching (Reymond et al. 2002b) and by use of mouse genome resources available via the ENSEMBL project (www.ensembl.org). This produced a list of 104 genes and, after excluding the cluster of 22 keratin-associated proteins (Krtap) genes, we tested the remaining 82 genes. An efficient Taqman assay was obtained for 78 of these genes. We also included 15 control genes, six of which are Hsa21 orthologs, but are not triplicated in Ts65Dn, and six normalization genes (Methods).

A total of 99 genes were compared between Ts65Dn (Ts) and euploid (Eu) mice in two developmental stages (postnatal day 30 and $11 \mathrm{mo}$ ) and six different tissues (brain, heart, kidney, liver, lung, and muscle). For each tissue under study, equal quantities of RNA from four individual male mice were pooled. Ts65Dn mice, although not isogenic, are a mixture of only two strains (C57B6 and $\mathrm{C} 3 \mathrm{H}$; www.jax.org), so the level of genetic variation is considerably less than that in humans. Pooling of individual mice, while reducing the variation seen, enables aneuploidyrelated differences to be identified without being confounded by experimental or inter-individual variation.

Example amplification plots are shown in Figure 1, and give an indication of the precision of the five replicates. Overall, the standard errors (SEM) of Ts/Eu expression ratios are low, 85\% genes have a SEM $<0.05$ (the standard errors for all genes are given in Supplemental Fig. 1). The use of qPCR enabled the quantification of almost all genes in the study; on average $86 \%$ were detected for a particular tissue (Table 1 ). This is considerably better than microarray platforms, where generally 30\%-60\% of genes are detected, depending on the tissue (data not shown). 


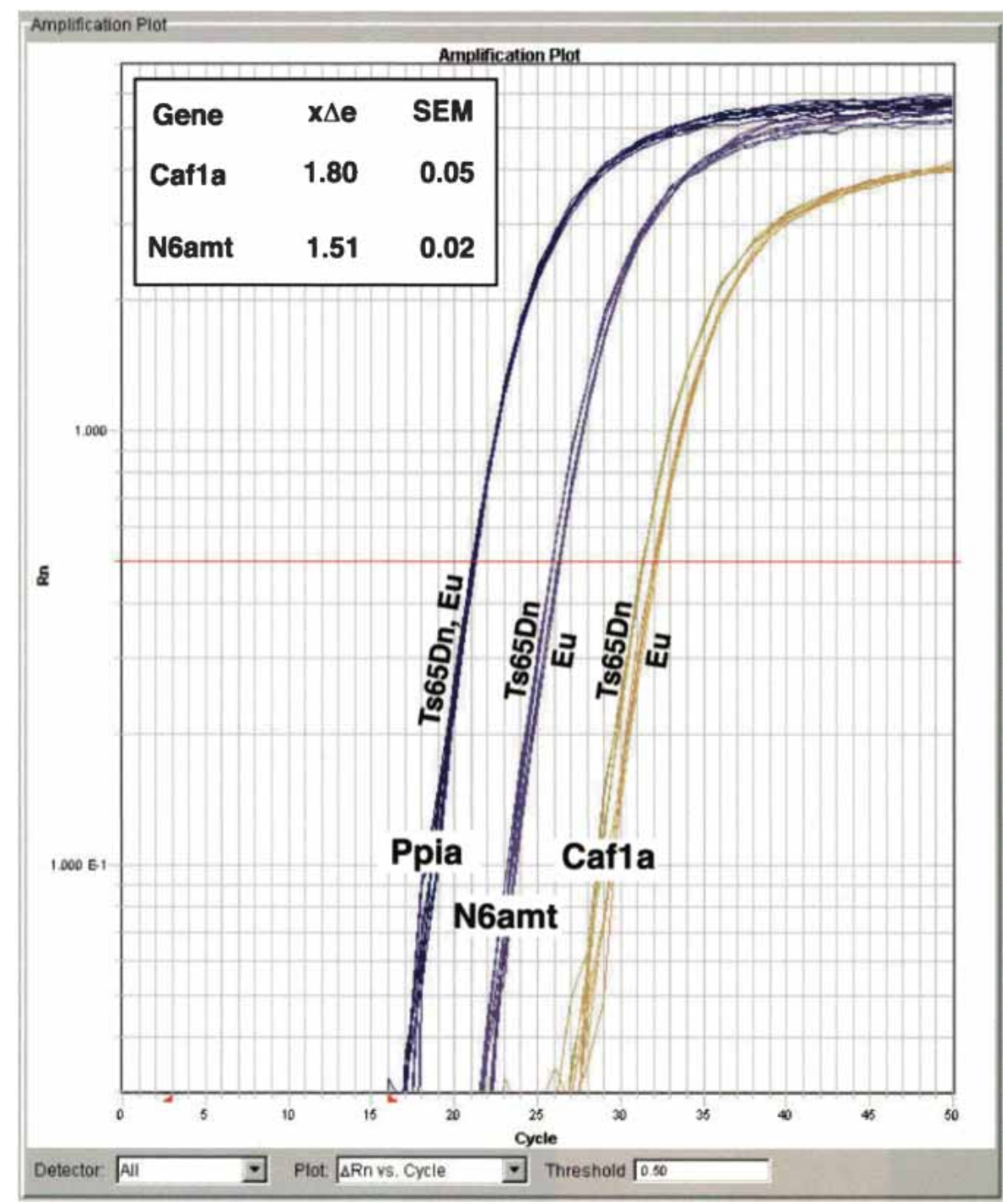

Figure 1 Example of Taqman real-time PCR amplification plot from P30 kidney of Ts65Dn and euploid mice. Two test genes (N6amt and C21 orf18) and one normalization gene (Ppia) are shown. For each mouse genotype and gene there are five replicates. (Inset) The normalized relative expression of Ts65Dn to euploid ( $x \Delta \mathrm{e})$ and the standard error (SEM).

The results for all genes and tissues are given in Figure 2 and summarized in Table 1. Expression results are represented as the normalized relative expression ratio $\mathrm{Ts} / \mathrm{Eu}(\mathrm{x} \Delta \mathrm{e})$. On the basis of the $95 \%$ confidence interval of each value, Figure 2 also indicates how genes are expressed compared with the ratios 1.0 and 1.5. The mean for the control genes is close to 1.0 for all tissues, demonstrating that the normalization strategy we used is reliable. For the triplicated test genes, the mean is close to the theoretical value of 1.5 -fold, suggesting that the increase in DNA copy number leads to the expected increase in RNA levels. However, the data are significantly skewed $\left(\mathrm{g}_{1}=2.70, P<0.001\right.$; Sokal and Rohlf 1995); many genes are expressed at a level significantly different from 1.5-fold in each tissue (Figs. 2, 3). On average, $45 \%$ of the genes are expressed at significantly lower than 1.5-fold, and $9 \%$ are not significantly different from 1.0 (Table 1 ). Strikingly, $18 \%$ of the trisomic genes are expressed at $>1.5$-fold. Thus, only approximately a third of the genes (37\%) are expressed at the theoretical value of 1.5 -fold.

Although the majority of genes are expressed between 1.0- and 1.5-fold, for the molecular pathology of DS, it is interesting to identify genes that have expression ratios significantly different from these levels (Fig. 2). Genes that are consistently expressed at higher levels in many tissues, for example Adamts 1 and Mx1, may be considered candidates for aspects of the DS phenotype. One gene in particular, Ankrd3 appears as a candidate for the heart defects seen in $40 \%$ of DS individuals (Epstein 2001), as it is highly overexpressed in both P30 (2.83-fold) and 11 mo (5.09-fold) heart and maps within the DS heart critical region (Barlow et al. 2001). Although Ts65Dn mice do not have the heart defect, Ankrd3 overexpression in humans in combination with genomic variation outside of Hsa21 may be causitive. Conversely, the $9 \%$ of genes that are not significantly different from 1.0 are less likely to contribute to DS phenotypes.

The coefficients of variation $(\mathrm{CV}$, a measure of the variation independent of the mean; Sokal and Rohlf 1995) of the test and control genes are significantly different $(t$-test, $P=0.015)$; this indicates that expression of the triplicated genes is more variable than the control genes. This difference, and the fact that the majority $(63 \%)$ of genes are not expressed at 1.5 -fold, suggests that there are considerable differences in gene responses to aneuploidy. If this variation in expression was stochastic, we would expect that there would be no correlation in gene expression when comparing different tissues. Plotting $\mathrm{x} \Delta \mathrm{e}$ for the genes (Fig. 4), indicated that there might be a similar expression pattern between the different tissues and stages. To test this, correlations in gene expression between different tissues were calculated (Table 2 ) and show that the fold expression in the same tissue at the two different developmental stages are highly correlated. Many of the other tissues also show a high degree of correlation in gene expression (Table 2). In contrast, for the control genes, only five (of the total of 45 pairwise comparisons) showed a significant correlation, and $\mathrm{r}$ was very small (mean value 0.01 , data not shown), indicating that the variation observed in the control genes was due to either experimental variation or natural variation in gene expression. In summary, the data indicate that expression is not disrupted in a random manner, but is reproducible for most genes across most tissues.

\section{DISCUSSION}

The small differences in gene expression measured in this study are not easily detectable by other methods of RNA quantification. Other studies have used microarrays and serial analysis of gene expression (SAGE) to study global gene expression changes in DS (FitzPatrick et al. 2002; Mao et al. 2003) and Ts65Dn (Chrast et al. 2000; Saran et al. 2003). Whereas these techniques can distinguish between trisomic and euploid individuals by considering 

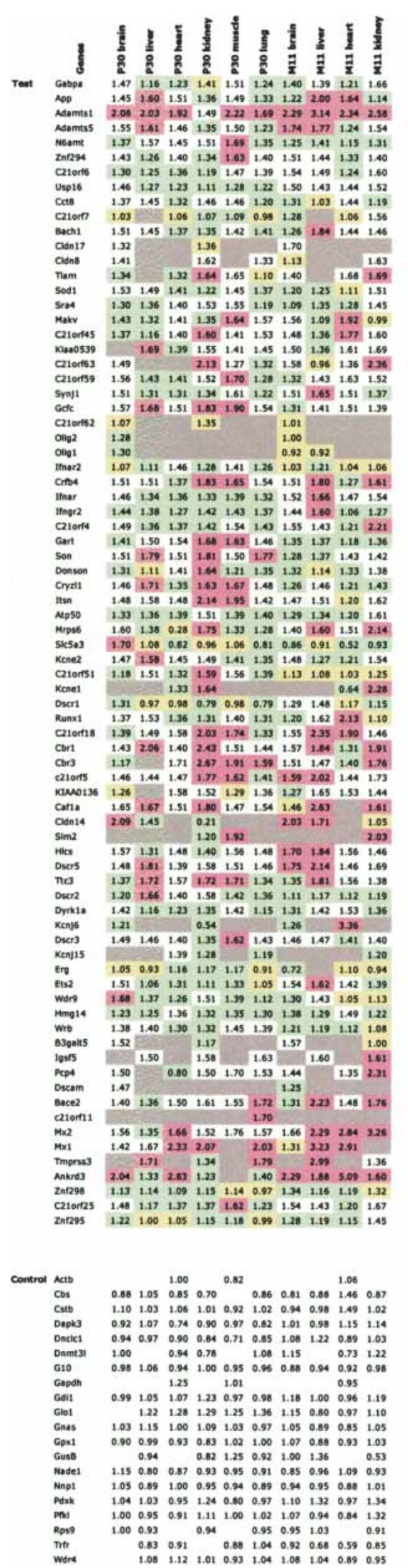

Figure 2 Normalized relative expression Ts/Eu $(x \Delta e)$. The values are the expression of a gene for Ts65Dn relative to Eu for the tissues and stages shown. The colors represent expression relative to the theoretical values 1.5 and 1.0 , based on $95 \% \mathrm{Cl}$ for the values. global expression-pattern differences, they are poor at assessing the effects of trisomy on the level of expression of individual Hsa21 genes. Real-time quantitative PCR has considerable advantages over these methods in that it can be used to accurately detect very small changes in expression, and the sensitivity means that expression values can be obtained for almost every gene of interest. qPCR thus has advantages over arrays to measure gene expression in aneuploidy and to measure normal expression variation as a quantitative trait (Cheung and Spielman 2002; Cheung et al. 2003; Schadt et al. 2003).

The data presented reveal that aneuploidy results in overexpression of the genes on the aneuploid chromosome. It is difficult to predict how changes in DNA copy-number affect gene expression relative to the diploid state. This has relevance for both studies of aneuploidy and transgenic studies, as the assumption of a direct relationship between DNA copy-number and relative RNA expression may not hold.

Down syndrome results from a complex interaction of genetic, environmental, and stochastic variation (Shapiro 1997; Pritchard and Kola 1999; Epstein 2001; Reeves et al. 2001). The data presented here suggest that expression from the aneuploid chromosome is similar across different tissues and developmental stages. This contrasts with the disruption in global gene expression noted in microarray studies (Chrast et al. 2000; FitzPatrick et al. 2002; Mao et al. 2003; Saran et al. 2003). It thus seems that there is an amplification of the initial variation that may, in turn, result in the extensive variability of the phenotype that characterizes DS. Our data show that aneuploidy results in a subtle and complex overexpression of genes from the aneuploid chromosome.

\section{METHODS}

\section{RNA Isolation and CDNA Preparation}

Total RNA was prepared from frozen tissues using Trizol (Invitrogen) according to the manufacturer's instructions. The quality of all RNA samples was checked using an Agilent 2100 Bioanalyzer (Agilent Technologies). In addition, littermates were used as control mice. Total RNA was converted to cDNA using Superscript II (Invitrogen) primed with poly d(T). For each tissue in the study, $6 \mu \mathrm{g}$ of total RNA was converted to cDNA in seven individual reverse-transcriptase reactions; these were then pooled and diluted $\sim 1: 14$. This provided enough cDNA for subsequent experiments.

\section{Project Design and Selection of Normalization Genes}

One of the major issues in qPCR analyses is the difficulty in normalizing input cDNA to provide an accurate comparison between tissues (Bustin 2002). We devised a strategy in which we analyzed three groups of genes, 82 test genes that are present in three copies in Ts65Dn, six normalization genes from which we selected three to normalize input cDNA for each tissue, and 15 control genes that are present in two copies in Ts65Dn (Ts) and euploid $(\mathrm{Eu})$. This latter group contained eight genes that are on human Hsa21 (Hsa21), but the mouse orthologs map to chromosomes 10 and 17, and seven that do not map to Hsa21. A working Taqman assay was obtained for 99 (95\%). Assays for four genes from the test group (Clic6, Grik1, Sh3bgr, Dscr6) did not have a sufficient efficiency, so these genes were excluded.

For each tissue tested, the expression of all control and normalization genes was compared between Ts65Dn and Eu. This enabled us to select three normalization genes that produced no difference in expression levels of the control genes between Ts65Dn and Eu (Table 1). The mean relative expression Ts/Eu ( $x \Delta \mathrm{e}$, see below for analysis) for these genes is $\sim 1$, indicating that the normalization genes chosen (see Supplemental Table 1) can reliably be used to normalize input cDNA quantity (Vandesompele et al. 2002).

\section{Genome Research \\ www.genome.org}




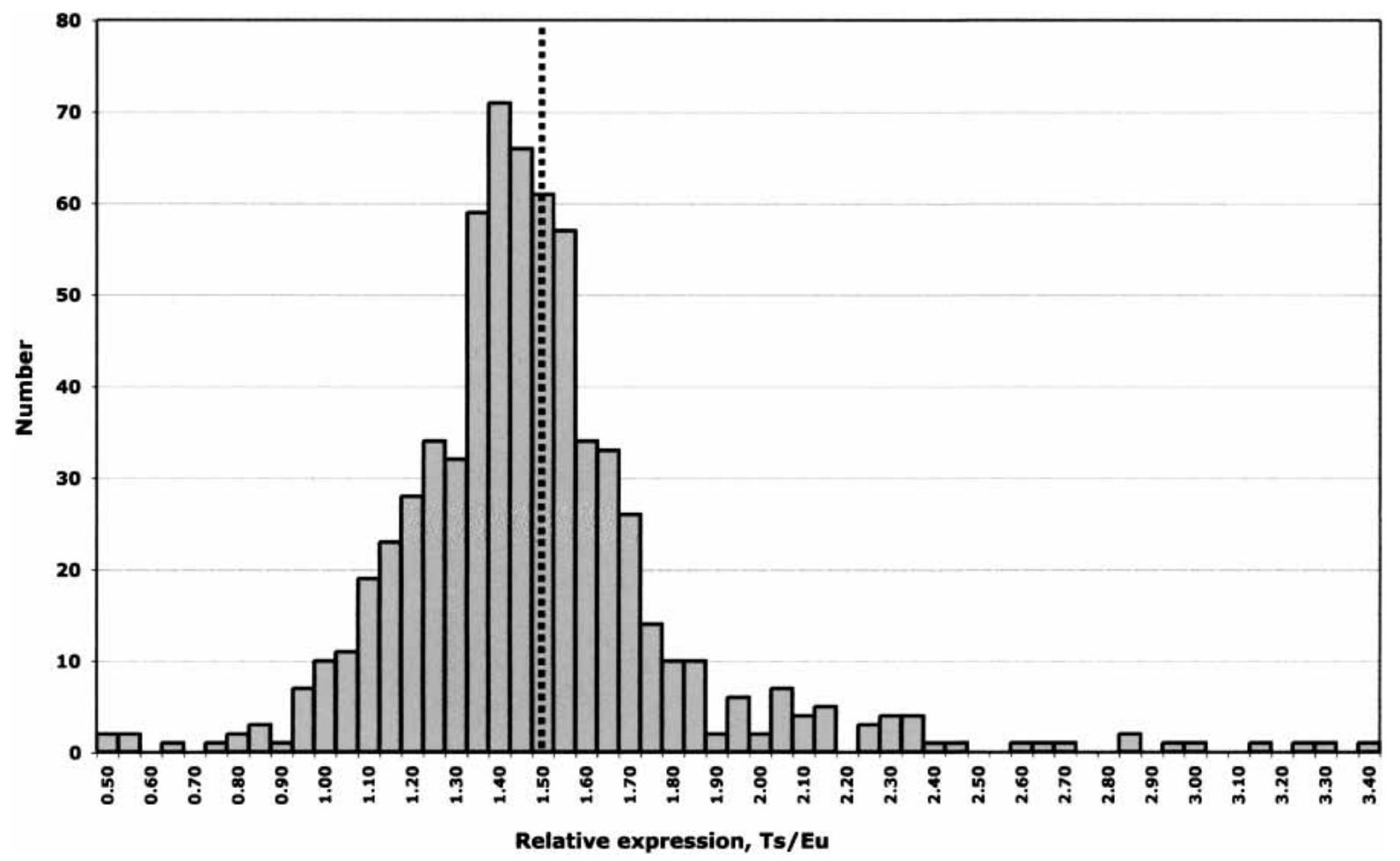

Figure 3 Histogram of normalized relative expression Ts/Eu $(x \Delta e)$. The values from Figure 2 are plotted into bins differing by 0.05 . The dotted line indicates the position of the value 1.5.

\section{Real-Time Quantitative PCR}

Taqman assays were designed using the program PrimerExpress (Applied Biosystems) with default parameters in every case. Where possible, assays were designed to span an intron, and for $89(90 \%)$ this was possible. Non intron-spanning assays were tested in standard + / - RT reactions of RNA samples for genomic contamination; in the majority of cases, no amplification was observed, and in the remainder, amplification was at least 10 cycles later in $-\mathrm{RT}$ compared with $+\mathrm{RT}$ reactions. Amplicon sequences where checked by BLAST against the mouse genome to ensure that they were specific for the gene being assayed. HPLCpurified FAM-TAMRA-labeled double-dye Taqman probes were obtained from Eurogentec (Seraing). The efficiency of each Taq- man assay was tested in a cDNA dilution series (Livak and Schmittgen 2001). Oligonucleotide and probe sequences, assay conditions, and calculated efficiencies are given in Supplemental Table 2.

All reactions used qPCR mastermix (RT-QP2X-03) from Eurogentec (Seraing). PCRs comparing Ts65Dn and Eu tissues were set up using a Biomek 2000 robot (Beckman), in a $10-\mu \mathrm{L}$ volume in 384-well plates with five replicates per sample. All PCRs were run in an ABI 7900 Sequence Detection System (Applied Biosystems) with the following conditions: $50^{\circ} \mathrm{C}$ for $2 \mathrm{~min}, 95^{\circ} \mathrm{C}$ for 10 min, and 50 cycles of $95^{\circ} \mathrm{C} 15 \mathrm{sec} / 60^{\circ} \mathrm{C}$ for $1 \mathrm{~min}$. For each tissue, three 384 well plates were required to analyze all genes, and each plate contained the appropriate normalization genes to control for any variability between the different plate runs.

Table 1. Summary Statistics for Expression Data

\begin{tabular}{|c|c|c|c|c|c|c|c|c|c|c|}
\hline \multirow[b]{2}{*}{ Tissue } & \multicolumn{3}{|c|}{ Control genes } & \multicolumn{6}{|c|}{ Test genes } & \multirow{2}{*}{$\begin{array}{l}\text { All genes } \\
\% \text { detectec }\end{array}$} \\
\hline & m & SD & CV & m & SD & CV & $\%<1.5(-1.0)$ & $\%-1.5$ & $\%>1.5$ & \\
\hline P30 brain & 1.00 & 0.08 & 7.52 & 1.43 & 0.20 & 13.93 & $38.0(7.0)$ & 54.9 & 7.0 & 91 \\
\hline P30 heart & 0.98 & 0.14 & 13.73 & 1.39 & 0.32 & 22.64 & $45.5(6.1)$ & 48.5 & 6.1 & 82 \\
\hline P30 kidney & 0.95 & 0.20 & 17.16 & 1.47 & 0.36 & 24.64 & $50.0(5.4)$ & 23.0 & 27.0 & 95 \\
\hline P30 liver & 1.00 & 0.11 & 10.80 & 1.42 & 0.24 & 16.98 & $50.8(8.2)$ & 26.2 & 23.0 & 77 \\
\hline P30 lung & 0.98 & 0.12 & 12.16 & 1.36 & 0.22 & 16.43 & $58.8(8.8)$ & 30.9 & 10.3 & 87 \\
\hline P30 muscle & 0.97 & 0.14 & 14.08 & 1.50 & 0.23 & 15.03 & $28.6(6.3)$ & 44.4 & 27.0 & 79 \\
\hline M11 brain & 1.01 & 0.11 & 10.68 & 1.39 & 0.26 & 19.02 & $52.8(11.1)$ & 37.5 & 9.7 & 91 \\
\hline M11 heart & 0.98 & 0.22 & 22.55 & 1.49 & 0.65 & 43.50 & $50.0(12.5)$ & 34.4 & 15.6 & 82 \\
\hline M11 kidney & 1.03 & 0.19 & 18.30 & 1.53 & 0.40 & 26.21 & $34.3(14.3)$ & 42.9 & 22.9 & 90 \\
\hline M11 liver & 0.99 & 0.17 & 17.41 & 1.60 & 0.49 & 30.63 & $34.9(9.5)$ & 28.6 & 36.5 & 81 \\
\hline mean & 0.99 & 0.15 & 14.44 & 1.46 & 0.34 & 22.90 & $44.5(8.9)$ & 37.2 & 18.3 & 86 \\
\hline
\end{tabular}

Numbers represent the statistic for the expression level of genes for the given tissue. For all genes, the percentage of genes for which reliable expression data could be obtained is shown in the last column. (m) Mean; (SD) standard deviation; (CV) coefficient of variation. 
Downloaded from genome.cshlp.org on April 26, 2023 - Published by Cold Spring Harbor Laboratory Press
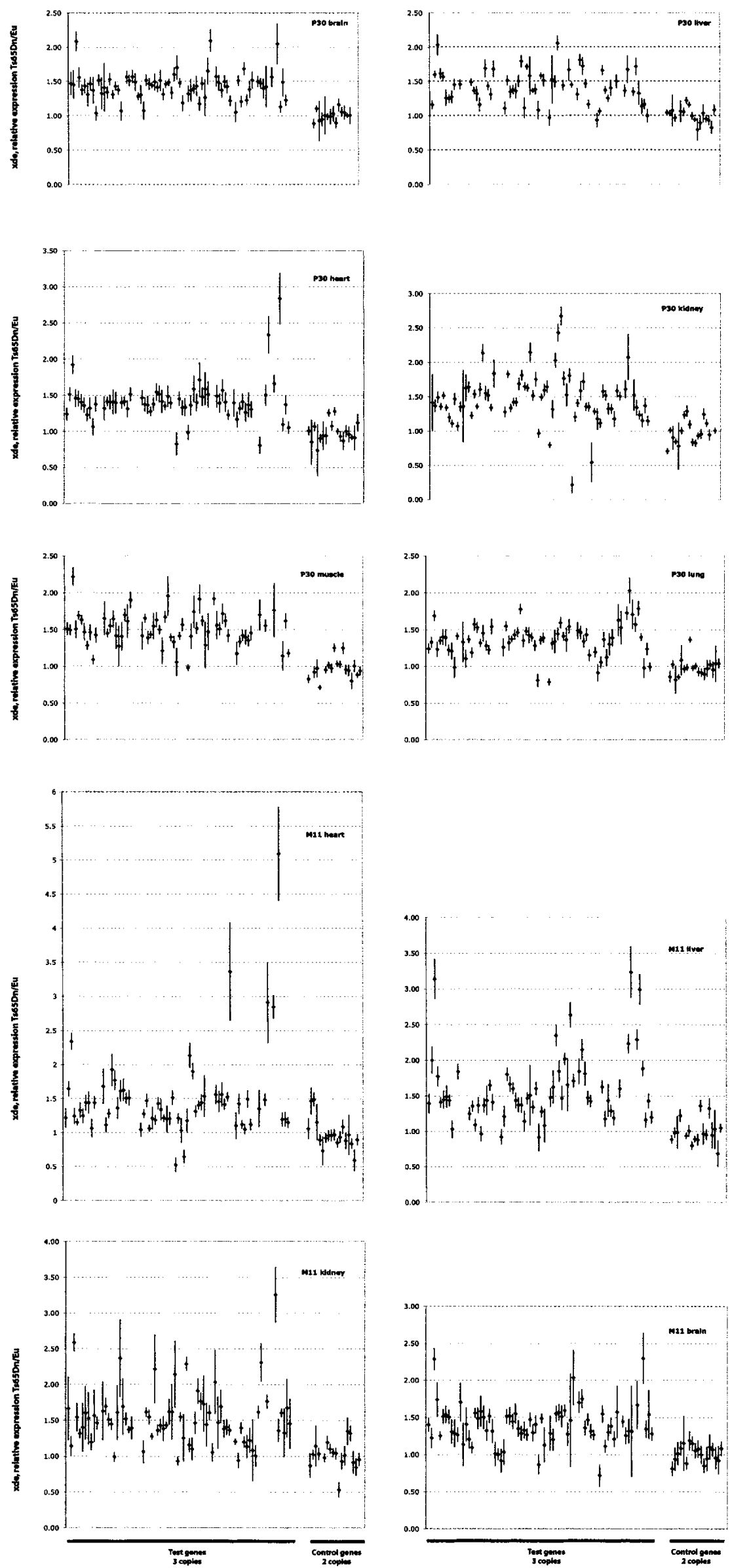

Figure 4 Graphs of normalized relative expression Ts/ Eu $(x \Delta \mathrm{e})$. Points represent the values from Figure 2 and bars represent the $95 \% \mathrm{Cl}$ of these values. The $x$-axis has genes plotted along mouse Chromosome 16 for the test genes. The $y$-axis represents $x \Delta$. The list and order of genes for each tissue is given in Figure 2. 
Table 2. Gene Expression Correlations Between Tissues

\begin{tabular}{|c|c|c|c|c|c|c|c|c|c|}
\hline & P30 liver & P30 heart & P30 kidney & P30 muscle & P30 lung & M11 brain & M11 liver & M11 heart & M11 kidney \\
\hline P30 Brain & $0.27^{*}$ & & & $0.28^{*}$ & $0.27^{*}$ & $0.49^{\star \star *}$ & $0.40^{* *}$ & & \\
\hline P30 Liver & & $0.52^{\star \star *}$ & $0.60^{* * *}$ & $0.52^{* \star *}$ & $0.58^{\star \star *}$ & & $0.36^{\star \star *}$ & & \\
\hline P30 Heart & & & $0.50^{* * *}$ & $0.56^{* * *}$ & $0.61^{\text {*** }}$ & $0.26^{*}$ & $0.43^{* * *}$ & $0.45^{\star \star \star}$ & \\
\hline P30 Kidney & & & & $0.48^{* \star *}$ & $0.53^{\star \star *}$ & & & & $0.47^{* * *}$ \\
\hline P30 Muscle & & & & & $0.58^{\star \star *}$ & $0.35^{\star * *}$ & $0.39 * *$ & $0.32^{*}$ & $0.34^{* *}$ \\
\hline P30 Lung & & & & & & $0.32^{* *}$ & $0.39^{* *}$ & $0.34^{* *}$ & $0.39^{* *}$ \\
\hline M11 Brain & & & & & & & $0.49^{\star * *}$ & $0.40^{* *}$ & $0.48^{\star * *}$ \\
\hline M11 Liver & & & & & & & & $0.53^{* \star *}$ & $0.37^{\star * *}$ \\
\hline M11 Heart & & & & & & & & & $0.25^{\text {** }}$ \\
\hline M11 Kidney & & & & & & & & & \\
\hline
\end{tabular}

Spearman rank correlation coefficients ( $r$ ) were calculated for all pairwise tissue combinations. Comparisons between the same tissue at two different developmental stages are in bold. Only significant $r$ are shown $(P<0.05)$. $P$ values $\left(^{*}\right) 0.01<P<0.05 ;\left({ }^{* *}\right) 0.001<P<0.01 ;\left({ }^{* * *}\right) P<0.001$.

\section{Data Analysis}

For qPCR, the raw data consist of PCR cycle number required to reach a fluorescence threshold $(\mathrm{Ct})$. Raw $\mathrm{Ct}$ values were obtained using SDS 2.0 (Applied Biosystems). Subsequent assay efficiency calculations and measurements of relative expression were carried out in Excel (Microsoft). To calculate the normalized relative expression ratio $\mathrm{Ts} / \mathrm{Eu}(\mathrm{x} \Delta \mathrm{e})$ and error values, we used the method geNorm (Vandesompele et al. 2002). For statistical analyses, we used the programs Minitab, Prism, and Excel.

\section{Reliability of Quantitative PCR}

To test for systematic biases within our qPCR results, we looked for correlations between the following values: the PCR efficiency (E), threshold cycle $(\mathrm{Ct})$, expression ratio Ts/Eu $(\mathrm{x} \Delta \mathrm{e})$, and the standard error (SEM) of $x \Delta e$. There is no correlation between $x \Delta e$ and either $\mathrm{E}$ or $\mathrm{Ct}$ (data not shown). Thus, individual Taqman assays expression ratios $(\mathrm{x} \Delta \mathrm{e})$ are reliable independently of the efficiency of the assay efficiency or the level of expression of the gene (as Ct is correlated with expression level). There is, however, a correlation between $\mathrm{Ct}$ and the standard error (see Supplemental Fig. 2). For experiments with Cts above $\sim 30-35$, the standard error increases as the precision of replicate measurements decreases. However, because $\mathrm{x} \Delta \mathrm{e}$ is independent of $\mathrm{Ct}$ and se, the measured $\mathrm{x} \Delta \mathrm{e}$ is reliable. It should be noted that for all experiments, the Ct values were within the range of values obtained for assay efficiency calculations.

\section{ACKNOWLEDGMENTS}

We thank Manolis Dermitzakis, Marguerite Neerman-Arbez, and Michael Morris for discussions and critical reading of the manuscript, and Mylène Docquier and Patrick Descombes of the NCCR Genomics Platform. This work was funded by the Fondation Jérôme Lejeune, the ChildCare Foundation, The Swiss National Science Foundation (3100-057149.99/1), the EU/OFES (QLG1CT-2002-00816), and the NCCR Frontiers in Genetics.

The publication costs of this article were defrayed in part by payment of page charges. This article must therefore be hereby marked "advertisement" in accordance with 18 USC section 1734 solely to indicate this fact.

\section{REFERENCES}

Akeson, E.C., Lambert, J.P., Narayanswami, S., Gardiner, K., Bechtel, L.J., and Davisson, M.T. 2001. Ts65Dn-localization of the translocation breakpoint and trisomic gene content in a mouse model for Down syndrome. Cytogenet. Cell. Genet. 93: 270-276.

Barlow, G.M., Chen, X.N., Shi, Z.Y., Lyons, G.E., Kurnit, D.M., Celle, L., Spinner, N.B., Zackai, E., Pettenati, M.J., Van Riper, A.J., et al. 2001. Down syndrome congenital heart disease: A narrowed region and a candidate gene. Genet. Med. 3: 91-101.

Baxter, L.L., Moran, T.H., Richtsmeier, J.T., Troncoso, J., and Reeves, R.H. 2000. Discovery and genetic localization of Down syndrome cerebellar phenotypes using the Ts65Dn mouse. Hum. Mol. Genet 9: 195-202.

Bustin, S.A. 2002. Quantification of mRNA using real-time reverse transcription PCR (RT-PCR): Trends and problems. J. Mol. Endocrinol. 29: 23-39.

Cheung, V.G. and Spielman, R.S. 2002. The genetics of variation in gene expression. Nat. Genet. 32: 522-525.

Cheung, V.G., Conlin, L.K., Weber, T.M., Arcaro, M., Kuang-Yu, J., Morley, M., and Spielman, R.S. 2003. Natural variation in human gene expression assessed in lymphoblastoid cells. Nat. Genet. 33: $422-425$.

Chrast, R., Scott, H.S., Papasavvas, M.P., Rossier, C., Antonarakis, E.S., Barras, C., Davisson, M.T., Schmidt, C., Estivill, X., Dierssen, M., et al. 2000. The mouse brain transcriptome by SAGE: Differences in gene expression between P30 brains of the partial trisomy 16 mouse model of Down syndrome (Ts65Dn) and normals. Genome Res. 10: $2006-2021$.

Davisson, M.T., Schmidt, C., and Akeson, E.C. 1990. Segmental trisomy of murine Chromosome 16: A new model system for studying Down syndrome. Prog. Clin. Biol. Res. 360: 263-280.

Davisson, M., Bechtel, L., Akeson, E., Fortna, A., Slavov, D., and Gardiner, K. 2001. Evolutionary breakpoints on human chromosome 21. 78: 99-106.

Epstein, C.J. 2001. Down syndrome (trisomy 21). In The metabolic and molecular bases of inherited diseases (eds. C.R. Scrive et al.), pp. 1223-1256. McGraw-Hill, New York.

FitzPatrick, D.R., Ramsay, J., McGill, N.I., Shade, M., Carothers, A.D., and Hastie, N.D. 2002. Transcriptome analysis of human autosomal trisomy. Hum. Mol. Genet. 11: 3249-3256.

Hattori, M., Fujiyama, A., Taylor, T.D., Watanabe, H., Yada, T., Park, H.S., Toyoda, A., Ishii, K., Totoki, Y., Choi, D.K., et al. 2000. The DNA sequence of human chromosome 21. Nature 405: 311-319.

Livak, K.J. and Schmittgen, T.D. 2001. Analysis of relative gene expression data using real-time quantitative PCR and the 2(-Delta Delta C(T)) Method. Methods 25: 402-408.

Mao, R., Zielke, C.L., Zielke, H.R., and Pevsner, J. 2003. Global up-regulation of chromosome 21 gene expression in the developing down syndrome brain. Genomics 81: 457-467.

Pletcher, M.T., Wiltshire, T., Cabin, D.E., Villanueva, M., and Reeves, R.H. 2001. Use of comparative physical and sequence mapping to annotate mouse Chromosome 16 and human chromosome 21 . Genomics 74: 45-54.

Pritchard, M. and Kola, I. 1999. The 'gene dosage effect' hypothesis versus the 'amplified developmental instability' hypothesis in Down syndrome. J. Neural Transmission 57: 293-303.

Reeves, R.H., Irving, N.G., Moran, T.H., Wohn, A., Kitt, C., Sisodia, S.S., Schmidt, C., Bronson, R.T., and Davisson, M.T. 1995. A mouse model for Down syndrome exhibits learning and behavioural deficits. Nat. Genet. 11: 177-184.

Reeves, R.H., Baxter, L.L., and Richtsmeier, J.T. 2001. Too much of a good thing: Mechanisms of gene action in Down syndrome. Trends Genet. 17: 83-88.

Reymond, A., Friedli, M., Henrichsen, C.N., Chapot, F., Deutsch, S., Ucla, C., Rossier, C., Lyle, R., Guipponi, M., and Antonarakis, E.S 2001. From PREDs and open reading frames to cDNA isolation: Revisiting the human chromosome 21 transcription map. Genomics 78: $46-54$.

Reymond, A., Camargo, A.A., Deutsch, S., Stevenson, B.J., Parmigiani, R.B., Ucla, C., Bettoni, F., Rossier, C., Lyle, R., Guipponi, M., et al. 2002a. Nineteen additional unpredicted transcripts from human 


\section{Lyle et al.}

chromosome 21. Genomics 79: 824-832.

Reymond, A., Marigo, V., Yayiaoglu, M.B., Leoni, A., Ucla, C., Scamuffa, N., Caccioppoli, C., Dermitzakis, E.T., Lyle, R., Banfi, S., et al. 2002b. Human chromosome 21 gene expression atlas in the mouse. Nature 420: $582-586$.

Richtsmeier, J.T., Baxter, L.L., and Reeves, R.H. 2000. Parallels of craniofacial maldevelopment in Down syndrome and Ts65Dn mice. Dev. Dyn. 217: 137-145

Saran, N.G., Pletcher, M.T., Natale, J.E., Cheng, Y., and Reeves, R.H. 2003. Global disruption of the cerebellar transcriptome in a Down syndrome mouse model. Hum. Mol. Genet. 12: 2013-2019.

Schadt, E.E., Monks, S.A., Drake, T.A., Lusis, A.J., Che, N., Colinayo, V., Ruff, T.G., Milligan, S.B., Lamb, J.R., Cavet, G., et al. 2003. Genetics of gene expression surveyed in maize, mouse and man. Nature 422: 297-302.

Shapiro, B.L. 1997. Whither Down syndrome critical regions? Hum.
Genet. 99: 421-423.

Sokal, R. and Rohlf, F. 1995. Biometry. Freeman, New York.

Vandesompele, J., De Preter, K., Pattyn, F., Poppe, B., Van Roy, N., De Paepe, A., and Speleman, F. 2002. Accurate normalization of real-time quantitative RT-PCR data by geometric averaging of multiple internal control genes. Genome Biol. 3: 1-11.

\section{WEB SITE REFERENCES}

www.ensembl.org; Ensembl homepage.

www.jax.org; Jackson laboratories.

Received October 17, 2003; accepted in revised form April 15, 2004. 


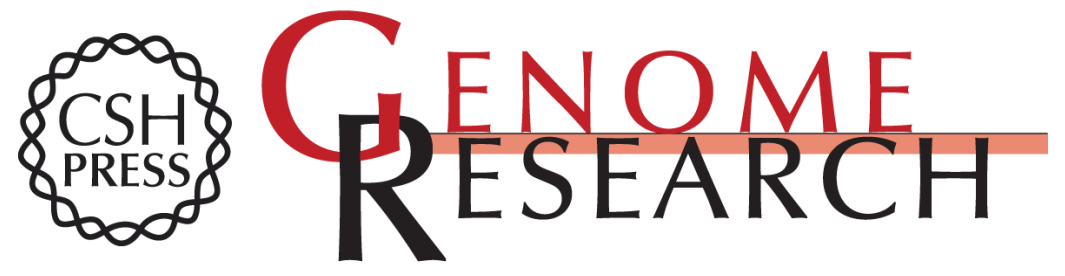

\section{Gene Expression From the Aneuploid Chromosome in a Trisomy Mouse Model of Down Syndrome}

Robert Lyle, Corinne Gehrig, Charlotte Neergaard-Henrichsen, et al.

Genome Res. 2004 14: 1268-1274

Access the most recent version at doi:10.1101/gr.2090904

Supplemental Material

References

License

Email Alerting Service
http://genome.cshlp.org/content/suppl/2004/06/17/14.7.1268.DC1

This article cites 23 articles, 2 of which can be accessed free at: http://genome.cshlp.org/content/14/7/1268.full.html\#ref-list-1

Receive free email alerts when new articles cite this article - sign up in the box at the top right corner of the article or click here.

\section{Affordable, Accurate Sequencing.}

To subscribe to Genome Research go to: https://genome.cshlp.org/subscriptions 